\title{
PENDAMPINGAN PEMBUKUAN SEDERHANA BAGI USAHA KERAJINAN ENCENG GONDOK DAN UMKM PEMULA DI SURABAYA
}

\section{SIMPLE BOOKING ASSISTANCE FOR ENCENG GONDOK CRAFTS AND BEGINNERS IN SURABAYA}

\author{
Supriyati $^{\# 1}$, Gunasti Hudiwinarsih ${ }^{\# 2}$, Muazaroh ${ }^{\# 3}$

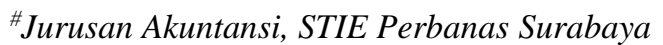 \\ Jl. Nginden Semolo 34-36 Surabaya \\ ${ }^{1}$ supriyati@perbanas.ac.id \\ 2 astiteperbanas.ac.id \\ 3 muazaroheperbanas.ac.id
}

\begin{abstract}
Abstrak
Usaha kerajinan eceng gondok merupakan salah satu usaha kerajinan di kota surabaya yang mampu memperkenalkan produknya ke manca negara. Bisnis ini telah dirintis sejak 2008 dan memiliki pasar produk yang luas. Namun, masalah utama yang dihadapi mitra adalah administrasi pembukuan yang tidak terstruktur dan stabil karena kendala sumber daya, operasi yang tidak rutin dan fokus pemilik pada kegiatan produksi. Kegiatan pengabdian masyarakat ini dilakukan untuk dapat membantu mitra dalam menyusun pelaporan keuangan secara terstruktur dan mantap. Kegiatan pengabdian kepada masyarakat yang telah dilakukan antara lain wawancara dengan mitra untuk memahami proses bisnis usaha kerajinan, pendampingan pengelolaan usaha khususnya pencatatan transaksi mitra usaha, serta penyusunan SOP dan draft Buku Panduan Akuntansi Bisnis Sederhana. Hasil tim pelaksana kegiatan pengabdian masyarakat telah mampu menyelesaikan kegiatan pengabdian kepada masyarakat dengan hasil yang diperoleh berupa 1) peningkatan kesadaran dan pemahaman mitra kerja tentang pentingnya pembukuan untuk operasional usaha, 2) penyusunan laporan keuangan sederhana yang berguna bagi mitra kerja, 3) penyusunan SOP dan draft Buku Panduan usaha Simple Craft. Kegiatan pengabdian kepada masyarakat ke depan perlu terus dikembangkan agar semakin banyak pelaku usaha yang tergabung dalam usaha mandiri atau pemula dapat mengembangkan usaha dengan baik dan berkelanjutan. Oleh karena itu, diperlukan dukungan pemerintah dan akademisi.
\end{abstract}

Kata Kunci: Usaha Kerajinan Tangan, Pelaporan Keuangan, Wawancara, Pendampingan

\section{Abstract}

The water hyacinth handicraft business is one of the handicraft businesses in the city of Surabaya that is able to introduce its products to foreign countries. This business has been initiated since 2008 and has a broad product market. However, the main problem faced by partners is that the administration of bookkeeping is not structured and stable due to resource constraints, non-routine operations and the owner's focus on production activities. This community service activity is carried out to be able to help partners compile financial reporting in a structured and steady manner. Community service activities that have been carried out include interviews with partners to understand the business processes of handicraft businesses, business management assistance, especially recording business partners' transactions, and the preparation of SOPs and draft Simple Business Accounting Handbooks. The results of the community service activity implementation team have been able to complete community service activities with the results obtained in the form of 1) increased awareness and understanding of partners about the importance of bookkeeping for business operations, 2) the preparation of simple financial statements that are useful for partners, 3) the compilation of SOPs and the draft Guidebook Simple Craft business. Community service activities in the future need to be developed further so that more and more business people belonging to independent or beginner businesses can develop businesses well and sustainably. Therefore, the support of the government and academia is needed.

Keywords: Handicraft Business, Financial Reporting, Interview, assistance

\section{PENDAHULUAN}

Data Kementrian Koperasi dan UKM menyebutkan jumlah UMKM di Indonesia semakin berkembang dan meningkat sejak tahun 2014. Perkembangan di Indonesia secara nasional menunjukkan kegiatan UKM merupakan usaha yang konsisten dan mampu berkembang. UMKM telah menjadi ujung tombak dan penyelamat perekonomian negara karena potensi UKM memberikan sumbangan terbesar dan signifikan pada Produk Domestik Bruto (PDB) dalam hal ini penyerapan tenaga kerja (Achmad, 2018). Seiring bertambahnya tahun, sektor informal menjadi trend yang masih berkembang di tengah masyarakat kita. Kebijakan yang diambil Presiden Jokowi adalah melakukan pemberdayaan UKM yang mencakup: 1) peningkatan akses pada 
sumber pembiayaan, 2) pengembangan kewirausahaan, 3) peningkatan pasar produk UKM dan 4) reformasi birokrasi (Achmad, 2018).

Jawa timur saat ini telah memberikan kontribusi terbesar dari total 34 propinsi di Indonesia. Hal ini terbukti koperasi dan UKM dalam PDRB Jawa timur cukup fantastis sebesar Rp 884 triliun. Demikian dengan kota Surabaya saja sebanyak 26.800 UKM aktif tahun 2017. Hal ini juga dinaungi oleh Peraturan Daerah Nomor 4 Tahun 2007 Tentang Pemberdayaan Koperasi, Usaha Mikro Kecil dan Menengah, serta Peraturan Daerah Propinsi Jawa Timur Nomor 6 Tahun 2011 Tentang Pemberdayaan Usaha Mikro Kecil dan Menengah. Upaya menumbuhkan UMKM dilandasi tiga alasan, yaitu: 1) UKM bertujuan untuk menyerap tenaga kerja, 2) pemerataan pendapatan, 3) pengentasan kemiskinan.

Tabel 1. Jumlah UMKM Kota Surabaya Tahun 2014-2017

\begin{tabular}{ccc}
\hline TAHUN & $\begin{array}{c}\text { UMKM } \\
\text { (ORANG) }\end{array}$ & $\begin{array}{c}\text { USAHA MIKRO } \\
\text { DAN KECIL }\end{array}$ \\
\hline 2014 & 27.926 & 25.353 \\
\hline 2015 & 28.391 & 25.147 \\
\hline 2016 & 28.759 & 26.037 \\
\hline 2017 & 29.507 & 26.800 \\
\hline Sumber: Laporan BPS tahun 2017
\end{tabular}

Membangun sektor industri yang maju dimulai dari pembinaan yang tepat dan saat ini banyak industri kecil yang tumbuh dan berkembang di masyarakat namun bila tidak dibimbing dan dibina akan sulit berkembang dan tetap bertahan (Adi dkk, 2018). Industri kecil saat ini sangat diminati oleh orang awam karena industri kecil memiliki daya tarik sendiri dan keberadaannya bisa diakses oleh siapapun. Pertukaran informasi, barang dan jasa sebagaimana penerapan MEA akan meningkatkan arus perdagangan. Hal ini tentunya perlu diadakan pembenahan baik dalam bidang pendidikan, ekonomi, sosial maupun budaya (Agrissto dkk, 2017). Kreativitas diperlukan dalam pengembangan UKM itu sendiri (Rizqy dan Rini, 2018). Banyak cara yang dapat digunakan khususnya agar masyarakat dapat meningkatkan kepedulian terhadap lingkungan.

Badan Ekonomi Kreatif Indonesia menunjukkan ada enam belas subsektor ekonomi kreatif yang masih harus dikembangkan (Angga dkk, 2019). Salah satunya adalah kerajinan atau craft yang berkaitan dengan kreasi, produksi dan distribusi produk yang dibuat oleh tenaga pengrajin yang berawal dari desain awal sampai proses penyelesaian produknya. Usaha kerajinan tangan berbahan enceng gondok (gulma) merupakan salah satu UKM yang masih bertahan di Kota Surabaya. Uasaha kerajinan ini diperkenalkan oleh Ibu Wiwit Manfaati. Produk hasil Wiwit Collection ini diberi nama WITROVE. Wiwit Collection dirintis dari tahun 2008 dimana Ibu Wiwit awalnya adalah seorang ibu rumah tangga. Beliau menekuni usaha kreasi enceng gondok karena melihat banyak enceng gondok yang menutupi sungai Kalimas Surabaya dan tidak dimanfaatkan.

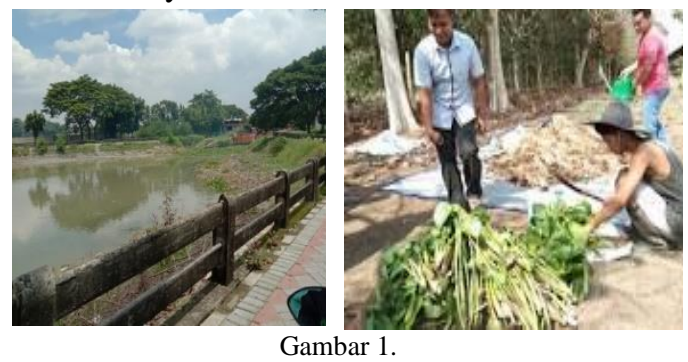

Kondisi Sungai Kalimas dan Kegiatan Masyarakat di sekitar sungai

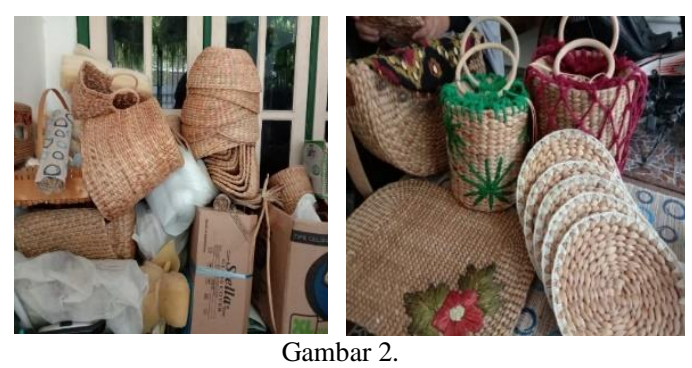

Produk Kerajinan Berbahan Enceng Gondok

Enceng gondok memang merusak citra sungai bahkan menjadi pembendung sampah. Dalam jangka panjang bila dibiarkan tentu tidak sedap dipandang, namun dengan penggunaan enceng gondok sebagai bahan utama Witrove ini, sekarang tidak lagi dianggap gulma semata. Ibu Wiwit dengan dibantu suaminya Bapak Supardi sekarang lebih fokus pada proses produksi. Wiwit Collection ini telah mampu menjadi salah satu UKM idaman Pemkot Surabaya. Wiwit Collection juga melibatkan tetangga satu kampung ataupun wilayah lain seperti Wiyung, bangkingan dan Lakarsantri. Dan kini ribuan barang jadi telah dijual dengan cukup banyak variasi seperti tas, sandal, kursi, peralatan dapur, dsb.

Wiwit Collection memang memiliki branding yang sudah dikenal dan memperoleh omzet yang besar, namun kendala utama yang dihadapi ketersediaan SDM yang terbatas. Selama ini usaha tersebut hanya ditangani oleh $\mathrm{Bu}$ Wiwit bersama suaminya saja, juga dibantu siswa/mahasiswa 
magang ditempatnya. Beliau tidak memiliki pegawai tetap karena proses produksinya ini sangat membutuhkan ketrampilan khusus. Beliau pernah memperkerjakan tetangga atau rekanan lain dalam proses produksi, namun produk yang dihasilkan tidak sesuai kualitas yang diinginkan pemesan. Karena itu, ketika ada pesanan dalam jumlah besar selalu membutuhkan waktu yang cukup lama.

Omzet yang besar dan pesanan yang berkelanjutan tampaknya tidak diikuti dengan pembukuan yang rapi dan terstruktur. Keterbatasan sumberdaya, pesanan yang tidak rutin, kesibukan pemilik mengurusi produksi saja, tidak adanya mahasiswa/siswa magang di bidang pembukuan menyebabkan pemilik tidak memiliki catatan pembukuan yang terstruktur. Disisi lain, Bu Wiwit juga sebagai pelopor dan pengajar di Kegiatan Pahlawan Ekonomi Surabaya yang dirintis Bu Risma sejak tahun 2018 dan telah memperkenalkan produk unggulan kota Surabaya ini sehingga mau tidak mau $\mathrm{Bu}$ Wiwit harus memberikan contoh aspek pembukuan ini pada UKM lainnya khususnya bagi pemula.

Penggunaan informasi akuntansi dalam pengambilan keputusan akan mempengaruhi kinerja perusahaan, khususnya bagi UMKM. Informasi akuntansi diperlukan dalam pengambilan keputusan investasi dan akan mendukung ketepatan wirausaha dalam mempertimbangkan konsekuensi keuangan atas keputusan yang diambil. Pembukuan dan pelaporan keuangan merupakan hal yang cukup penting dalam pertumbuhan dan perkembangan usahanya (Jati, 2004), (Gunasti dan Supriyati, 2019). Sebagaimana adanya Stndar Akuntansi Keuangan EMKM (Entitas Mikro Kecil dan Menengah) yang sudah diberlakukan 1 Januari 2018 lalu menjadi kewajiban bagi pelaku usaha menyusun pelaporan keuangan.

Kegiatan pengabdian masyarakat yang dilakukan bertujuan untuk:1) mengetahui kesiapan pelaku usaha kerajinan dan UKM pemula dalam pelaporan keuangan, 2) membantu pelaku usaha kerajinan dan UKM pemula menyusun pelaporan keuangan, 3) memotret transaksi bisnis usaha kerajinan agar menjadi role model kasus pada modul akuntansi pengantar yang akan disusun. Sebagai langkah awal kegiatan pengabdian kepada masyarakat internal ini lebih difokuskan pembenahan pelaporan keuangan dan pengelolaan usaha yang nantinya dapat mendukung keberlanjutan usaha khususnya bagi UKM pemula

\section{TARGET DAN LUARAN}

Sasaran pengabdian masyarakat program studi akuntansi adalah pemilik usaha enceng gondok dan UKM pemula di Surabaya. Pengabdian masyarakat tersebut dilakukan dengan mempertimbangkan kondisi UKM, manfaat sangat besar bagi keberlanjutan usaha. Pelaporan keuangan bagi UKM akan membantu UKM dalam menyampaikan kinerja keuangan dan posisi keuangan UKM sekarang dan masa depan. Luaran yang didapat adalah modul akuntansi pengantar bagi UKM.

\section{METODE PELAKSANAAN}

Permasalahan utama yang dihadapi mitra saat ini adalah belum tersusunnya pencatatan akuntansi atau pembukuan yang terstruktur dan ejeg. Masalah ini muncul disebabkan adanya keterbatasan sumberdaya, pesanan yang tidak rutin, kesibukan pemiliki yang fokus di produksi, tidak adanya siswa/mahasiswa magang. Tim pelaksana bersamasama dengan mitra berkolaborasi dalam menjalankan kegiatan pengabdian masyarakat intenal ini yang membantu membenahi dan mendisain pembukuan sederhana yang akan mempermudah operasional mitra sekarang dan masa datang. Metode pengabdian yang dilakukan adalah 1) wawancara dan kunjungan langsung kepada mitra, 2) pendampingan usaha khususnya pelaporan keuangan, 3) penyusunan draft buku panduan akuntansi sederhana.

Langkah pertama adalah wawancara dan kunjungan langsung kepada mitra. Kegiatan ini difokuskan untuk menggali masalah dan latar belakang masalah yang dihadapi mitra. Wawancara ini dilakukan secara langsung kepada pemilik maupun pihak lain yang memiliki keterikatan dengan usaha mitra misalkan ketua kegiatan Pahlawan Ekonomi Surabaya. Wawancara dan kunjungan ini sekaligus sebagai media pembelajaran pentingnya pembukuan bagi mitra yang disampaikan tim pelaksana yang memang memiliki kompetensi di bidang akuntansi/pembukuan.

Langkah kedua adalah pendampingan usaha khususnya pelaporan keuangan mitra. Tim pelaksana mengamati transaksi yang rutin dan tidak rutin dilakukan mitra, mengamati media atau sarana yang dimiliki mitra yang dapat digunakan, juga sekaligus menyediakan sarana pembukuan seperti buku jurnal, 
buku kas bahkan memperkenalkan software aplikasi sederhana berbasis handphone/internet yang disesuaikan dengan kemampuan mitra. Kegiatan pendampingan ini juga diikuti kegiatan lainnya seperti memberikan konsultasi pengelolaan bisnis dan pelaporan keuangan baik kepada mitra maupun UKM lain yang membutuhkan melalui kegiatan pahlawan ekonomi.

Langkah ketiga adalah membantu menyusun SOP dan draft buku panduan akuntansi sederhana bagi UKM sektor kerajinan tangan. Guna menjamin usaha mampu berlangsung sampai jangka panjang, diperlukan dokumen formal yang dapat digunakan oleh pemilik dan pegawai yang bertanggungjawab sebagai acuan bertindak dalam operasional. Mitra perlu dibuatkan Standar Operational Procedure (SOP) pengelolaan bisnis dan pelaporan keuangan. Kegiatan operasional mitra khususnya di bidang usaha sektor kerajinan tangan menjadi hal menarik untuk digunakan dalam proses pembelajaran. Langkah berikutnya adalah menyusun draft buku panduan akuntansi sederhana yang akan menjadi bahasan di mata kuliah Akuntansi Pengantar II/ETAP

\section{HASIL DAN PEMBAHASAN}

Kegiatan pengabdian masyarakat ini melibatkan dosen yang memiliki kompetensi di bidang akuntansi dan manajemen, juga dibantu 2 orang mahasiswa akuntansi. Kegiatan pengabdian ini memperoleh dukungan Pak Doni selaku ketua penggagas Pahlawan Ekonomi Surabaya dengan memberikan kesempatan tim pelaksana pengabdian masyarakat dalam kegiatan konsultasi manajemen keuangan bagi UKM pemula.

Kegiatan awal yang dilakukan adalah wawancara tim pelaksana dengan salah satu UKM yang menjadi mitra, yaitu Ibu Wiwit Manfaati dikediamannya Perum Kebraon Indah Permai Surabaya tanggal 10 Pebruari 2020. Hasil yang diperoleh dari wawancana adalah bahwa selama ini mitra belum sempat melakukan pembukuan secara ajeg. $\mathrm{Bu}$ wiwit pernah diajari putranya untuk melakukan pembukuan, namun karena harus mengejar omzet bersama suaminya saja akhirnya kegiatan pembukuan tidak pernah dijalankan sampai hari ini. Namun, beliau tahu dan paham manfaat dari pembukuan tersebut karena selama ini ketika beliau bergelut dengan kegiatan Pahlawan Ekonomi Surabaya beliau menjadi tertuntut memberikan contoh kepada UKM pemula.

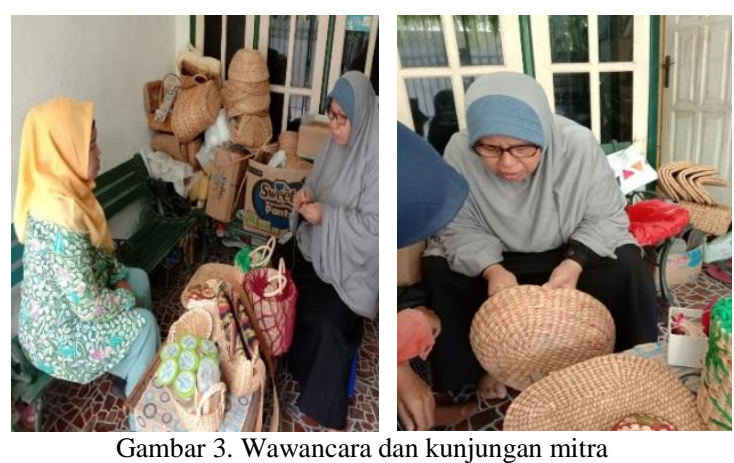

Kegiatan kedua adalah pendampingan usaha khususnya pelaporan keuangan mitra. Kegiatan pendampingan ini dibantu oleh mahasiswa mata kuliah Akuntansi Pengantar 2 yang mendapatkan tugas menyusun laporan keuangan sederhana bagi usaha kerajinan tangan. Proses pendampingan ini tidak bisa dilakukan secara langsung kepada mitra karena terkendala adanya musibah nasional COVID19. Namun, kegiatan yang bisa dilakukan hanya pendampingan secara tidak langsung melalui WhatsApp. Demikian dengan kegiatan konsultasi kepada UKM pemula melalui kegiatan Pahlawan Ekonomi Surabaya juga tidak bisa dilakukan.

Pendampingan hanya dilakukan sekali hari Sabtu tanggal 29 Februari 2020 di Kaza Plaza Surabaya berupa kegiatan launching Pahlawan Ekonomi Surabaya Tahap 2 tahun 2020 yang bekerjasama dengan BPOM, Dinas Pengendalian Penduduk Pemberdayaan Perempuan dan Perlindungan Anak, Dinas Kebudayaan dan Pariwisata, Dinas Kesehatan, Dinas Perindustrian dan Perdagangan, Dinas Koperasi dan UMKM, DPM DPSP. Kegiatan ini diorientasikan pada UKM pemula atau warga yang minat menjadi UKM dimana outcome kegiatan ini berupa product expose, pembuatan vidio atau foto produk dengan motto " $G o$ Product, Go Digital, Go Financial, Go Global”. Target tim pengelola tahun 2020 akan tercipta 999 usaha mandiri dengan waktu pelaksanaan 6 bulan yang terbagi menjadi 2 kelompok, yaitu Basic atau pemula, dan intermediate atau yang punya usaha. Para peserta diperkenalkan beberapa kegiatan Pahlawan Ekonomi diantaranya pelatihan pembuatan produk, cluster produk, seleksi produk, konsultasi ahli, pameran produk, kerjasama dengan dinas terkait dan vendor, konsinyasi produk ke toko. 

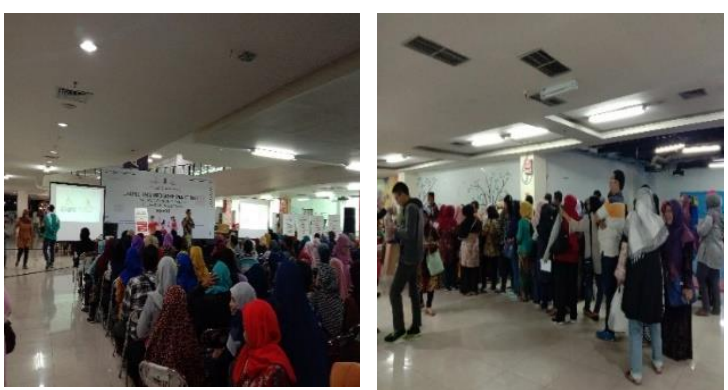

Gambar 4. Kegiatan launching dan pendampingan pahlawan ekonomi surabaya

Langkah selanjutnya yang dilakukan tim pelaksana bersama mitra adalah penyusunan SOP pengelolaan keuangan untuk pemula dan draft buku panduan akuntansi sederhana bagi usaha kerajinan. SOP pengelolaan keuangan ini merupakan prosedur baku yang harus dipahami mitra maupun pemilik UKM lainnya ketika akan menyusun pelaporan keuangan. SOP pengelolaan keuangan bermanfaat di masa sekarang karena akan dihasilkan pelaporan keuangan terstandar dan ajeg. Dimasa yang akan datang khususnya ketika pemilik sudah mampu memiliki pegawai akan bermanfaat untuk petunjuk pelaksanaan penyusunan pelaporan keuangan. Pemilik atau UKM akan mampu melihat kinerja operasionalnya berhasil atau tidak, bagaimana keberlanjutan usaha menguntungkan atau tidak, dan pemilik juga mampu memenuhi tuntutan pihak lain seperti dinas terkait ketika akan mengajukan tender atau pendanaan. Bila SOP ini sudah selesai akan menjadi panduan bagi UKM pemula lainnya bahwa menyusun pembukuan dan laporan keuangan menjadi kegiatan utama dan mudah dilakukan.

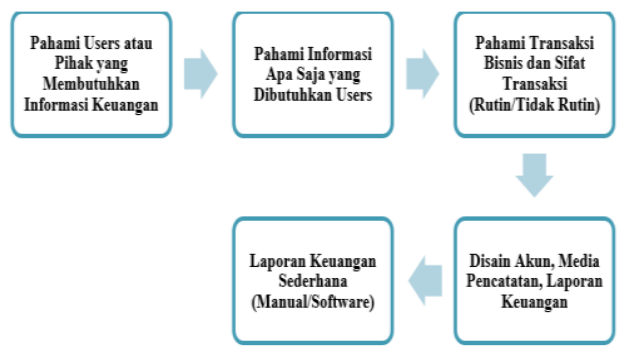

Gambar 5. Alur Proses Penvusunan SOP Pengelolaan Keuangan Bagi UKM Pemula

Hasil kegiatan pengabdian masyarakat lainnya adalah tersusunnya draft Buku Panduan Akuntansi Sederhana bagi Usaha Kerajinan. Draft buku ini sebagai bagian dari Buku Ajar Akuntansi Pengantar 2 yang akan dikembangkan oleh tim dosen Akuntansi Pengantar. Pengenalan proses bisnis selama ini telah diberikan lewat pengajaran Akuntansi Pengantar 2 tentang akuntansi perusahaan jasa, perusahaan dagang dan manufaktur tanpa memahami proses bisnis yang sebenarnya. Hal ini akan sulit diterima dan dipahami mahasiswa ketika mereka nantinya bekerja di bidang usaha yang berbeda dengan yang diajarkan dosen di kelas. Misalkan: usaha kerajinan ini memiliki proses bisnis yang unik dan bukan usaha umum sehingga transaksi dan proses pencatatan perlu pertimbangan khusus. Draft buku ini didasarkan pada transaksi selama 1 bulan yang terjadi di mitra. Draft buku ini akan terdiri 4 bagian, yaitu: bagian-1 Siklus Bisnis Usaha Kerajinan, bagian-2 Kebijakan Akuntansi dan Pelaporan, bagian-3 Transaksi dan Pelaporan Akuntansi, bagian-4 Format Jurnal, Buku Besar, Laporan keuangan.

\section{KESIMPULAN}

Kegiatan pengabdian masyarakat ini dilakukan untuk membantu mitra yang bergerak di usaha kerajinan tangan berbahan eceng gondok. Produk yang dihasilkan sudah mampu diterima masyarakat sebagai salah satu produk unggulan kota Surabaya dan sudah diperkenalkan di negara lain. Usaha yang dikembangkan mitra ini dijadikan usaha percontohan untuk mencetak 999 usaha mandiri di kota Surabaya melalui kegiatan Pahlawan Ekonomi Surabaya. Permasalahan utama yang dihadapi mitra saat ini adalah belum tersusunnya pencatatan akuntansi atau pembukuan yang terstruktur dan ejeg. Masalah ini muncul disebabkan adanya keterbatasan sumberdaya, pesanan yang tidak rutin, kesibukan pemiliki yang fokus di produksi, tidak adanya siswa/mahasiswa magang. Tim pelaksana bersamasama dengan mitra berkolaborasi dalam menjalankan kegiatan pengabdian masyarakat intenal ini yang membantu membenahi dan mendisain pembukuan sederhana yang mempermudah operasional mitra sekarang dan masa datang. Metode pengabdian yang dilakukan adalah 1) wawancara dan kunjungan langsung kepada mitra, 2) pendampingan usaha khususnya pelaporan keuangan, 3) penyusunan draft buku panduan akuntansi sederhana.

Bersama mitra, tim pelaksana kegiatan pengabdian masyarakat telah mampu menyelesaikan kegiatan pengabdian masyarakat dengan hasil yang diperoleh berupa 1) meningkatnya kesadaran dan pemahaman mitra tentang pentingnya pembukuan untuk operasional usahanya, 2) tersusunnya laporan keuangan sederhana yang bermanfaat untuk mitra, 3) tersusunnya SOP dan draft Buku Panduan Sederhana Usaha kerajinan. Namun kendala dan kelemahan 
yang dihadapi oleh tim pelaksana adalah tidak dilakukan pendampingan secara langsung kepada mitra karena adanya musibah nasional COVID-19 sehingga data atau dokumen yang diperoleh masih sedikit. Karena itu, bila kondisi negara dan masyarakat kembali stabil kemungkinan pengembangan yang dapat dilakukan ole tim pelaksana antara lain penyusunan media atau pencatatan berbasis software aplikasi yang bisa dimanfaatkan mitra maupun UKM pemula lainnya, pengembangan draft Buku Panduan untuk transaksi bisnis lainnya agar bisa dikembangkan Buku Ajar yang dapat dimanfaatkan oleh mahasiswa dan pelaku bisnis.

Saran yang dapat disampaikan agar kegiatan pengabdian masyarakat dapat bermanfaat bagi mitra maupun pelaku UKM lainnya khususnya UKM pemula antara lain: a) Bila kondisi negara dan masyarakat sudah stabil, sebaiknya pendampingan pada mitra dapat dilakukan secara langsung khususnya bagi mahasiswa yang terlibat dalam kegiatan pengabdian masyarakat. Kegiatan ini menjadi media pembelajaran bagi mahasiswa dan sarana aktualisasi akan kompetensi mahasiswa; b) Perlu dipertimbangkan untuk mengembangkan software aplikasi sederhana sekaligus sosialisasi atau pelatihan penggunaan software apliaksi sederhana tersebut. Tidak semua UKM pemula memiliki pengetahuan teknologi yang baik. Mereka perlu dibekali pengetahuan manual operasi akuntansi dan pengoperasian software aplikasi sederhana agar mereka menjadi pelaku usaha yang madiri dan $G o$ Global dimasa datang; c) Perlu segera dikembangkan Buku Ajar Akuntansi Pengantar yang menampilkan studi kasus berbagai usaha bisnis agar mampu menjadi sarana pembelajaran dan bekal mahasiswa dan pelaku usaha mempelajari proses bisnis yang beragam. Misalkan di dalamnya ada kasus usaha kerajinan tangan, kuliner atau bisnis makanan, jasa foto copi, jahit dan disain mode, perhotelan, klinik kesehatan dan sebagainya.

\section{UCAPAN TERIMAKASIH}

Uacapan terima kasih disampaikan kepada Pusat Penelitian dan Pengabdian Masyarakat STIE Perbanas Surabaya yang telah memberikan dukungan pendanaan dan fasilitas sehingga kegiatan pengabdian masyarakat internal ini dapat berjalan dengan lancar. Juga disampaikan kepada pak Doni dan $\mathrm{Bu}$ Wiwit Manfaati selaku pengelola Pahlawan Ekonomi Surabaya sekaligus mitra yang telah memberikan kesempatan tim pelaksana menjalankan kegiatan pengabdian masyarakat dan bertukar pemikiran tentang pengembangan Go Financial bagi UKM pemula di Surabaya

\section{DAFTAR PUSTAKA}

[1] Achmad Amiruddin. 2018. Pemberdayaan Usaha Kecil Menengah (UKM) Binaan Dinas Perdagangan Kota Surabaya dalam Upaya Meningkatkan Kesejahteraan. Makalah Ilmu Administrasi Negara FISIP Universitas Airlangga.

[2] Adi Suparno, Hendi Suhendi, Rizal Rachman, Toni Arifin dan Mayya Nurbayanti. 2018. Strategi Pengembangan Usaha Pada UMKM Baju Bayi Indra Collection. Jurnal Pengabdian Kepada Masyarakat BSI Vol. 1 No. 2 Agustus 2018, hal 208214

[3] Agrissto Bintang Aji Pradana, Ari Suryawan dan Tabah Subekti. 2017. Pemberdayaan Masyarakat Menghadapi MEA Melalui Pelatihan Ketrampilan di Kota Magelang. Warta LPM Vol.20 No. 1 Maret 2017, hal 17-23.

[4] Angga Sucitra Handrayana, Imas Maesaroh, Maman Sudirman dan Nana Setiana. 2019. Pengembangan Usaha Mikro Diamond Glassycraft Kabupaten Kuningan Propinsi Jawa Barat. Jurnal Publika Pengabdian Masyarakat Vol. 1 No. 1 Februari 2019, hal 1-7

[5] Gunasti dan Supriyati. 2019. Accounting and Tax Knowledge Bagi usaha Kecil dan Menengah Sub Sektor Jasa. Jurnal Pengabdian dan Pemberdayaan Masyarakat, Vol 3 No 1, hal 71-76.

[6] Jati Hironnymus, B. 2004. Menumbuhkan Kebiasaan Usaha Kecil Menyusun Laporan Keuangan. Jurnal Bisnis dan Usahaman, 2 (2), 210-218.

[7] Mahrus Ali dan Debi Olivia Sari. 2013. Pelatihan kerajinan Tangan Dari Kain Flanel Sebagai Pemberdayaan. Jurnal Inovasi dan Kewirausahaan Vol.2 No.2 Mei 2013, hal 136139

[8] Peraturan Pemerintah Nomor 17 Tahun 2013 Tentang Pelaksanaan Undang-Undang Nomor 20 Tahun 2008 Tentang Usaha Mikro Kecil Menengah

[9] RPJM (Rencana Pembangunan Jangka Menengah Daerah) Kota Surabaya untuk periode 2016-202

[10]Rizky Fadhlina Putri dan Rini Fadhlillah Putri. 2018. Pelatihan Pemanfaatan Barang Bekas Menjadi Barang Yang Bernilai Ekonomi. Jurnal Pengabdian Masyarakat Amaliyah Vol. 2 No. 1 Mei 2018, hal 37-42

[11] Undang Undang Nomor 20 Tahun 2008 tentang Usaha Mikro, Kecil dan Menengah

[12] Yesi Gusmania dan Fitrah Amelia. 2019. Pendampingan Pembuatan Kerajinan tangan Dari kain Flanel Untuk Menunjang Perekonomian Keluarga Sebagai Usaha Kecil Menengah Masyarakat di Kelurahan Sei Langkai. Jurnal Minda Baharu Vol. 3 No. 1 Juli 2019, hal 59-65

[13]Zanuar Rifai dan Luzi Dwi Oktaviana. 2018. Pelatihan Aplikasi Teknis Online Marketplace Pada Sentra UMKM Banyumas Pratistha Harsa Untuk Pemasaran Produk Secara Online. Jurnal Pengabdian Kepada Masyarakat BSI Vol. 1 No. 3 Agustus 2018, hal 593-599 